\title{
Response of Posidonia oceanica to burial dynamics
}

\author{
Marta Manzanera $^{1,4}$, Teresa Alcoverro ${ }^{2, *}$, Fiona Tomas ${ }^{3}$, Javier Romero ${ }^{4}$ \\ ${ }^{1}$ Agència Catalana de l'Aigua (ACA), C/ Provença, 204-208, Barcelona 08036, Spain \\ ${ }^{2}$ Centre d'Estudis Avançats de Blanes (CSIC), Girona 17300, Spain \\ ${ }^{3}$ Institut Mediterrani d'Estudis Avançats (CSIC-UIB), Illes Balears 07190, Spain \\ ${ }^{4}$ Departament d'Ecologia, Universitat de Barcelona, Barcelona 08028, Spain
}

\begin{abstract}
Seagrasses are able to colonise and dominate unstable sandy sediments but natural (storms, hurricanes, bioturbation) and anthropogenically induced (harbour building, beach nourishment, siltation) sediment arrivals can result in the total or partial burial of meadows. Within this context, our main objective was to experimentally establish the ability of long-living Posidonia oceanica, the dominant seagrass in the Mediterranean, to counteract natural or human-induced changes in sedimentation, and to specifically examine plant survival and plastic responses (vertical rhizome growth, branching, number of leaves and sheath length) to different levels of burial intensity, frequency, timing, and duration. Shoot population strongly declined with increasing sedimentation, reaching ca. $65 \%$ shoot disappearance with a burial level of $4 \mathrm{~cm}$, and undergoing $100 \%$ mortality with $9 \mathrm{~cm}$ burial. Sediment burial also enhanced shoot population decline regardless of frequency, duration or timing at which the burial event occurred. Nevertheless, at $4 \mathrm{~cm}$ burial, we detected some response capacity of plants to burial, consisting of rhizome elongation and rhizome branching. Rhizome vertical annual growth and internode length increased by $34 \%$ in the $4 \mathrm{~cm}$ treatment while it decreased by ca. $34 \%$ under high burial, although this response was meadow-specific. Rhizome branching also increased by ca. $36 \%$ at medium burial while being reduced by an average of $60 \%$ at high burial levels. On the other hand, there was no effect of burial on number of leaves or sheath length. Overall, this work provides experimental evidence that $P$. oceanica is very sensitive to sediment burial, although it displays a certain capacity to respond, which is site-specific. Our results highlight the importance of sedimentation rates as a limiting factor in determining the distribution of $P$. oceanica meadows, both under natural conditions and under man-altered regimes.
\end{abstract}

KEY WORDS: Seagrass $\cdot$ Burial $\cdot$ Sediment $\cdot$ Mortality $\cdot$ Mediterranean

\section{INTRODUCTION}

Coastal shallow benthic environments have very active sediment dynamics as a result of long-shore and cross-shore sediment redistribution, which result from processes occurring at different time scales and with consequences at the local and regional levels (Bailard 1981). Low frequency events, such as hurricanes and storms, can induce intense sedimentary dynamics, which may cause large-scale alteration of marine habitats (Marbà et al. 1994a,b, Preen et al. 1995, Fourqurean \& Rutten 2004), while bioturbation events exhibit high frequency and promote small-scale disturbances (Suchanek 1983, Philippart 1994, Valentine et al. 1994). Furthermore, increasing human activities in coastal areas worldwide (e.g. harbour building, beach nourishment, siltation) as well as global change (e.g. increase in hurricane and storm frequency, sea-level rise) have additional direct and indirect effects on sediment dynamics, and can seriously increase the frequency, duration and severity of events of erosion and/or oversedimentation (Short \& Neckles 1999, Ruiz \& Romero 2003, Badalamenti et al. 2006, Lionello et al. 2008).

The status of seagrass meadows is tightly linked to sedimentary dynamics (Jeudy de Grissac \& Boudouresque 1985). Seagrasses are able to colonise and dominate unstable sandy sediments thanks to vertical rhizome growth, which protects them from burial in the sand, and a root system that allows firm anchoring into the substrate (Marbà \& Duarte 1998). Yet living in such 
environments also makes seagrasses highly exposed and sensitive to changes in sedimentation (Boudouresque et al. 1984, Clarke \& Kirkman 1989, Marbà \& Duarte 1994, Vermaat et al. 1997). Indeed, humaninduced direct and indirect changes modifying these sedimentary regimes are among the main causes of worldwide seagrass decline (Shepherd et al. 1989, Walker \& McComb 1992, Short \& Wyllie-Echevarria 1996, Waycott et al. 2009). Well established seagrass meadows reach equilibrium when sediment influx is balanced by vertical rhizome growth (Gacia \& Duarte 2001). Excess sediment influxes can diminish the ability of seagrasses to adjust via vertical rhizome growth, resulting in the total or partial burial of meadows or in increases in water turbidity that cause major changes to the growth and photosynthetic potential of seagrass species (Duarte et al. 1997, Duarte 2002, Cruz-Palacios \& van Tussenbroek 2005). Understanding the response of seagrasses to sediment burial and erosion is important for predicting changes in seagrass meadows in response to natural or anthropogenic processes (Astier 1984, Pérès 1984, Blanc \& Grissac 1989, Bourcier 1989, Sánchez-Lizaso et al. 1990, Ruiz 2000, Boer 2007).

Seagrass response to different burial intensities has been assessed through both experimental and descriptive studies, and different thresholds of sediment tolerance have been established for several species (see recent review by Cabaço et al. 2008). These thresholds have essentially been determined by considering burial intensity as a key factor controlling seagrass abundance, dynamics and distribution. However, apart from burial intensity, consequences for plant performance will also depend on the duration of the event, the frequency of the event, and, at least in temperate species, the timing (e.g. season) when the event occurs. In order to better understand how sedimentation regimes determine seagrass communities (their abundance, dynamics and distribution), it is thus crucial to gain a deeper knowledge of the relationships between seagrasses and sediment dynamics. Such knowledge will also help predict and, eventually, mitigate the effects of man-induced sedimentation changes on these important ecosystems.

The seagrass Posidonia oceanica is a key species in the Mediterranean Sea, forming extensive meadows, which provide crucial habitat for many species, prevent coastal erosion and act as an important carbon sink (Mazzella et al. 1992, Vizzini et al. 2002, Duarte et al. 2005). This species is also characterised by a large canopy and a low rhizome elongation rate (ranging from $0.5-0.7 \mathrm{~cm} \mathrm{yr}^{-1}$ to $1.5-2 \mathrm{~cm} \mathrm{yr}^{-1}$; Jeudy de Grissac \& Boudouresque 1985), which could limit its capacity to recover or respond to sediment burial. Like many other seagrass ecosystems worldwide (Waycott et al. 2009), P. oceanica meadows are critically threatened due to increased anthropogenic pressure, and have suffered substantial reduction throughout the Mediterranean area (Ruiz et al. 2009). In fact, due to their ecological importance, the numerous anthropogenic threats to which they are exposed, and their low recovery capacity, $P$. oceanica beds have been declared a protected habitat within the European Habitats Directive (92/43/CEE). Natural disturbances like storms and anthropogenic coastal interventions such as beach nourishment or sand dredging result in sporadic sediment depositions in seagrass meadows (Erftemeijer \& Lewis 2006, González-Correa et al. 2009). Since events can have different levels of intensity, frequency, duration, or timing (Mortsch 1998), it is essential to consider them in order to predict their outcome effects. Within this context, our main objective was to experimentally establish the ability of $P$. oceanica to counteract natural or human-induced changes in sedimentation and, specifically, to examine the population decline and variability in plant responses to different levels of burial intensity, frequency, timing, and duration. We therefore conducted manipulative burial experiments where all these factors were modified in different meadows along the Spanish coast.

\section{MATERIALS AND METHODS}

Study sites. In order to encompass different sedimentation regimes that may influence plant responses, manipulative experiments on burial were conducted in distinct Posidonia oceanica meadows which differed in terms of exposure and depth. Experiments on burial intensity effects and timing were conducted at 3 meadows in order to establish a more general response: Shallow Protected (SHP), Shallow Exposed (SHE), at ca. $5 \mathrm{~m}$ depth, and Deep Exposed (DPE), at ca. $10 \mathrm{~m}$ depth. These meadows are located off the coast of Catalonia (NE coast of Spain, between ca. 42.04802 and $42.29516^{\circ} \mathrm{N}$ ), where shoot density ranges between 450 and 600 shoots $\mathrm{m}^{-2}$. As the sampling effort was considerable, we reduced the spatial extension for the rest of the experiments. The experiment on the effect of burial frequency was conducted in 2 meadows (SHE and DPE), while the experiments on duration took place at SHE, since this typology is the most representative of the meadows of this coastal region.

Experimental approach. We conducted several in situ experiments in which we manipulated sediment levels within Posidonia oceanica stands in order to simulate different levels of burial intensity (by adding different amounts of sediment), frequency, duration and timing of sediment accretion. Sedimentation was manipulated within PVC cylinders $(35 \mathrm{~cm}$ high and $33 \mathrm{~cm}$ in diameter) which were planted approximately 
15 to $20 \mathrm{~cm}$ into the sea bottom, leaving ca. 20 to $15 \mathrm{~cm}$ of the cylinder above the sediment. Cylinders were haphazardly placed over the meadow, at least $1 \mathrm{~m}$ apart from each other, and treatments were randomly assigned to them. Each cylinder enclosed between 12 and 53 P. oceanica shoots, depending on meadow density and local patchiness. Before applying the different treatments, we ensured that the vertical distance between the ligulae of the outermost leaf of the shoot and the original sediment level was equivalent in all plots (ca. $3 \mathrm{~cm}$ below the ligula).

Variables measured, experimental procedures, and statistical analyses. Expt 1 - Effects of burial intensity on Posidonia oceanica shoot population decline and sublethal responses: These experiments were conducted at the 3 meadows (SHP, SHE, and DPE). Three experimental burial levels (intensities) were applied: 0 cm (control), ca. $4 \mathrm{~cm}$ (medium), and ca. $9 \mathrm{~cm}$ (high), and 3 replicate cylinders were used per experimental condition. Burial levels are expressed as centimeters of sand added from the ligulae of the oldest leaf to the experimental sediment height level, following the concept of 'degrees of burial' or 'sedimentary conditions' established by Boudouresque et al. (1984). Experiments began in September and ran for ca. 200 to $250 \mathrm{~d}$. Cylinders were visited monthly, when sediment level within each cylinder was checked, and sediment from the same meadow was gently added or removed by hand when necessary.

As an indicator of burial effect we measured population decline (as the number of shoots at each visit, expressed as a percentage relative to the initial). The observed changes in shoot density represented the balance between recruitment and mortality. At the end of the experiment we measured sublethal responses on the remaining shoots. Specifically, we measured the number of leaves per shoot, sheath length of the oldest standing leaf per shoot, branching rate (estimated as the ratio between the number of new shoots and number of initial shoots), and the vertical rhizome growth measured as the internodal distance during the experimental period. We also used the lepidochronology technique to estimate mean annual vertical rhizome growth, measured as the accumulated vertical growth during the year preceding the end of the experiment (Crouzet et al. 1983, Pergent \& Pergent-Martini 1991).

We used 2-way ANOVAs to assess the effect of meadow type (Fixed) and burial intensity (Fixed) on shoot population decline and rhizome branching (replicates were cylinders). For mean annual vertical rhizome growth, number of leaves, and sheath length we performed 3-way nested ANOVAs with 2 fixed crossed factors (burial intensity and meadow) and a random factor cylinder (nested to the interaction of the 2 factors). In this case the replicates where the shoots.
Expt 2-Effects of burial frequency on Posidonia oceanica shoot population decline: We conducted an experiment to assess shoot density response of the plant to discrete and periodical events of burial and erosion. Four treatments were applied: control $(C$, no sand addition), permanent burial ( $\mathrm{P}, 9 \mathrm{~cm}$ of sand added and maintained until the end of the experiment), high frequency burial $(\mathrm{H}, 9 \mathrm{~cm}$ of sand added at the beginning of the experiment, and alternatively removed or re-added every $15 \mathrm{~d}$ until the end of the experiment), and low frequency burial (L, $9 \mathrm{~cm}$ of sand added at the beginning of the experiment, and alternatively removed or re-added every $30 \mathrm{~d}$ until the end of the experiment). The experiment was conducted in 2 meadows (SHE and DPE), began in June, and ended after $115 \mathrm{~d}$. Effects of frequency burial on population decline (the surviving number of shoots at each visit, expressed as a percentage relative to the initial) were tested by means of a 2-way ANOVA (fixed and crossed factors frequency and meadow).

Expt 3-Effect of burial duration on Posidonia oceanica shoot population decline: We examined the effects of different time periods of burial on shoot population decline (the surviving number of shoots at each visit, expressed as a percentage relative to the initial). The following treatments were applied: control ( $\mathrm{C}$, no sand addition), short-term burial ( $\mathrm{S}, 9 \mathrm{~cm}$ of sand were added at the beginning of the experiment and removed after $22 \mathrm{~d}$ ), mid-term burial (M, $9 \mathrm{~cm}$ of sand added and removed after $42 \mathrm{~d}$ ), and long-term burial ( $L, 9 \mathrm{~cm}$ of sand added and removed after $77 \mathrm{~d}$ ). The experiment began in May, lasted 105 d, and was performed in the SHE meadow. We used 1-way ANOVA to assess effects of burial duration on population decline.

Expt 4-Influence of burial timing on Posidonia oceanica shoot population decline: To test for possible differences in shoot population decline (the surviving number of shoots at each visit, expressed as a percentage relative to the initial) associated with the timing of burial, an additional experiment was conducted in June (when seagrass vitality is at its maximum; Alcoverro et al. 1995) in the same meadows (SHP, SHE and DPEin order to compare it with results from Expt 1 (which had been initialised in September of the previous year). Here we compared initial and final shoot density between cylinders with high burial treatment (i.e. $9 \mathrm{~cm}$ ) versus controls, which were deployed in June and maintained for $190 \mathrm{~d}$ in the 3 meadows. Differences among meadows, timings (June, September), and burial intensity (Control, High) were assessed by means of a 3-way ANOVA (all fixed factors).

Statistical analyses. For all ANOVA models, variables were individually checked for normality, homogeneity of variance and outliers using exploratory data 
analysis procedures. Data were log transformed when necessary (Quinn \& Keough 2002). We used Tukey's HSD post-hoc tests to test for between-treatment differences for each significant variable.

\section{RESULTS}

\section{Effects of burial intensity on seagrass parameters}

Shoot density, rhizome growth and branching were significantly affected by the different levels of sediment burial (Tables 1 \& 2, Figs. 1 \& 2). The number of living shoots declined dramatically in the high and medium burial treatments, already reaching 30 to $50 \%$ (medium) and 80 to $90 \%$ (high) decreases relative to the initial population after ca. $130 \mathrm{~d}$, and causing nearly complete mortality of shoots (ca. 100\% mortality) at the end of the experiment in the high treatment (Table 1, Fig. 1). In the case of sublethal responses, high levels of burial reduced branching and annual vertical rhizome growth at all sites, whereas medium sedimentation caused a significant increase in those parameters (Table 2, Fig. 2). Branching showed a similar response in all meadows, increasing by ca. $36 \%$ at medium burial while being reduced by an average of $60 \%$ at high burial (Fig. 2). Vertical annual growth followed similar patterns, increasing $34 \%$ in the medium treatment while decreasing ca. $34 \%$ under high burial. Although the interaction term between burial and meadow was not significant (Table 2), the increase in the medium treatment was more noticeable in 1 meadow (DPE), where values were $50 \%$ higher than in the other 2 surveyed meadows (Table 3). Rhizome

Table 1. Posidonia oceanica. Results of the 2-way ANOVA to assess the effects of burial intensity $(\mathrm{C}=$ control, $\mathrm{M}=$ medium, $\mathrm{H}=$ high $)$ on \% seagrass shoot survival

\begin{tabular}{|lcrrrr|}
\hline Factor & df & \multicolumn{1}{c}{ MS } & \multicolumn{1}{c}{$F$} & \multicolumn{1}{c|}{ p } & Tukey \\
\hline Meadow & 2 & 287.10 & 0.586 & 0.568 & \\
Burial & 2 & 11042.33 & 22.541 & $<\mathbf{0 . 0 0 1}$ & $\mathrm{C}>\mathrm{M}>\mathrm{H}$ \\
Meadow $\times$ Burial & 4 & 290.23 & 0.592 & 0.673 & \\
Error & 16 & 489.86 & & & \\
\hline
\end{tabular}

internodal distances between successive leaves increased substantially for the medium burial treatment, and again this effect was more evident in the DPE meadow $(0.33 \pm 0.03 \mathrm{~cm})$ when compared to the other 2 meadows $(0.12 \pm 0.01 \mathrm{~cm})$. On the other hand, there was no significant effect of burial on number of leaves or sheath length (Fig. 2), even though a similar increasing trend was observed in the DPE meadow for the medium treatment (Table 2).
Table 2. Posidonia oceanica. Results of the ANOVAs to test for the effects of Shallow Exposed meadows

\begin{tabular}{|c|c|c|c|c|c|}
\hline Factor & df & MS & $F$ & $\mathrm{p}$ & Tukey \\
\hline \multicolumn{6}{|c|}{ Rhizome annual growth ${ }^{\mathrm{a}}$} \\
\hline Meadow & 2 & 28750.6 & 15.07 & $<0.001$ & $\mathrm{DPE}>\mathrm{SHP}=\mathrm{SHE}$ \\
\hline Burial & 2 & 10399.3 & 5.35 & 0.018 & $\mathrm{M}>\mathrm{C}>\mathrm{H}$ \\
\hline Meadow $\times$ Burial & 4 & 692.7 & 0.34 & 0.845 & \\
\hline $\begin{array}{l}\text { Cylinder } \\
(\text { Meadow } \times \text { Burial })\end{array}$ & 13 & 2243.6 & 3.30 & $<0.001$ & \\
\hline Error & 122 & 679.0 & & & \\
\hline \multicolumn{6}{|l|}{ Branching } \\
\hline Meadow & 2 & 0.062 & 1.439 & 0.268 & \\
\hline Burial & 2 & 0.194 & 4.459 & 0.030 & $\mathrm{M}>\mathrm{C}>\mathrm{H}$ \\
\hline Meadow $\times$ Burial & 4 & 0.055 & 1.255 & 0.331 & \\
\hline Error & 15 & 0.044 & & & \\
\hline \multicolumn{6}{|l|}{ Sheath length ${ }^{a}$} \\
\hline Meadow & 2 & 22613.9 & 24.82 & $<0.001$ & $\mathrm{DPE}>\mathrm{SHP}>\mathrm{SHE}$ \\
\hline Burial & 1 & 1010.5 & 1.12 & 0.313 & \\
\hline Meadow $\times$ Burial & 2 & 1297.7 & 1.41 & 0.284 & \\
\hline $\begin{array}{l}\text { Cylinder } \\
\text { (Meadow } \times \text { Burial) }\end{array}$ & 10 & 971.0 & 2.12 & 0.030 & \\
\hline Error & 95 & 457.1 & & & \\
\hline \multicolumn{6}{|l|}{ Number of leaves } \\
\hline Meadow & 2 & 11.118 & 1.2165 & 0.344 & \\
\hline Burial & 1 & 0.000 & 0.0000 & 0.996 & \\
\hline Meadow $\times$ Burial & 1 & 4.627 & 0.4659 & 0.514 & \\
\hline $\begin{array}{l}\text { Cylinder } \\
(\text { Meadow } \times \text { Burial })\end{array}$ & 8 & 9.720 & 5.0589 & $<0.001$ & \\
\hline Error & 168 & 1.921 & & & \\
\hline
\end{tabular}



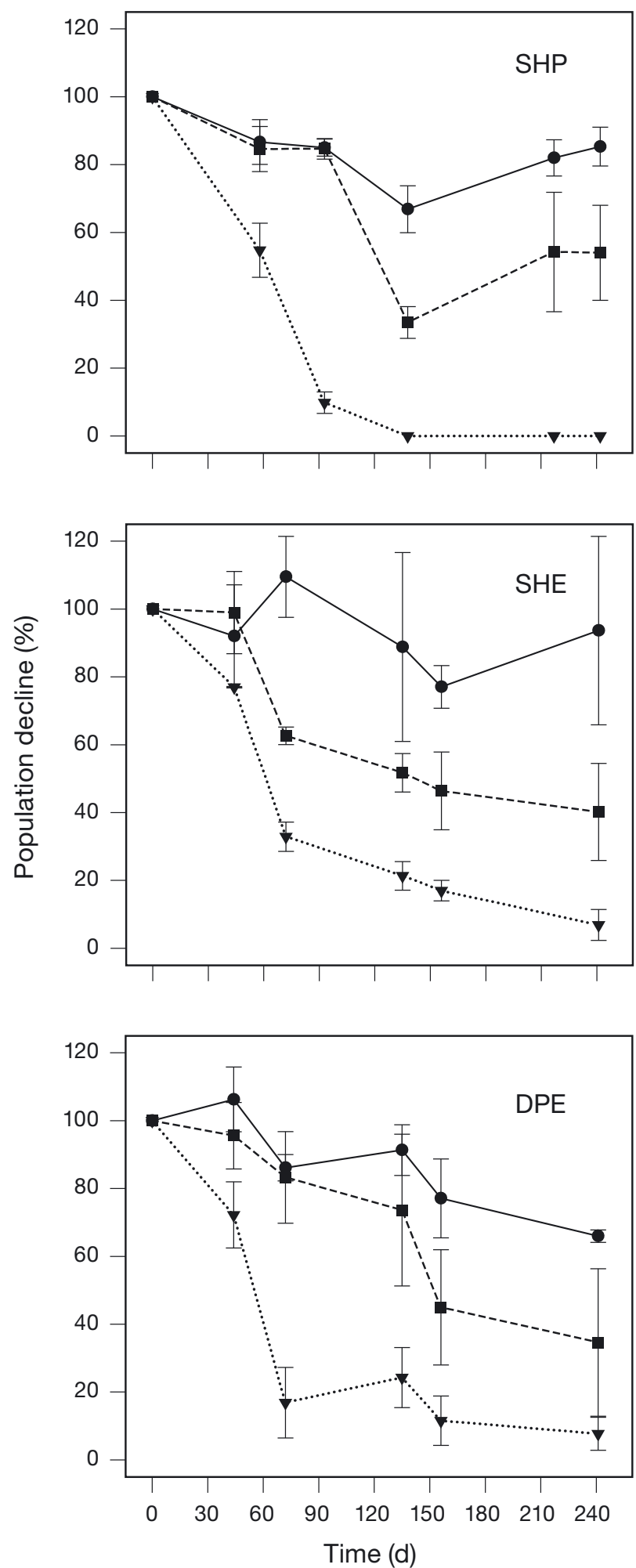

Fig. 1. Posidonia oceanica. Trends in population decline of shoots (surviving number of shoots, expressed as a percentage relative to the initial) under different levels of permanent burial: control $(0 \mathrm{~cm}$ : $)$, medium $(4 \mathrm{~cm}$ : $\mathbf{\square})$, and high $(9 \mathrm{~cm}: \boldsymbol{\nabla})$ at different sites $(\mathrm{SHP}=$ Shallow Protected, $\mathrm{SHE}=$ Shallow Exposed, DPE = Deep Exposed)
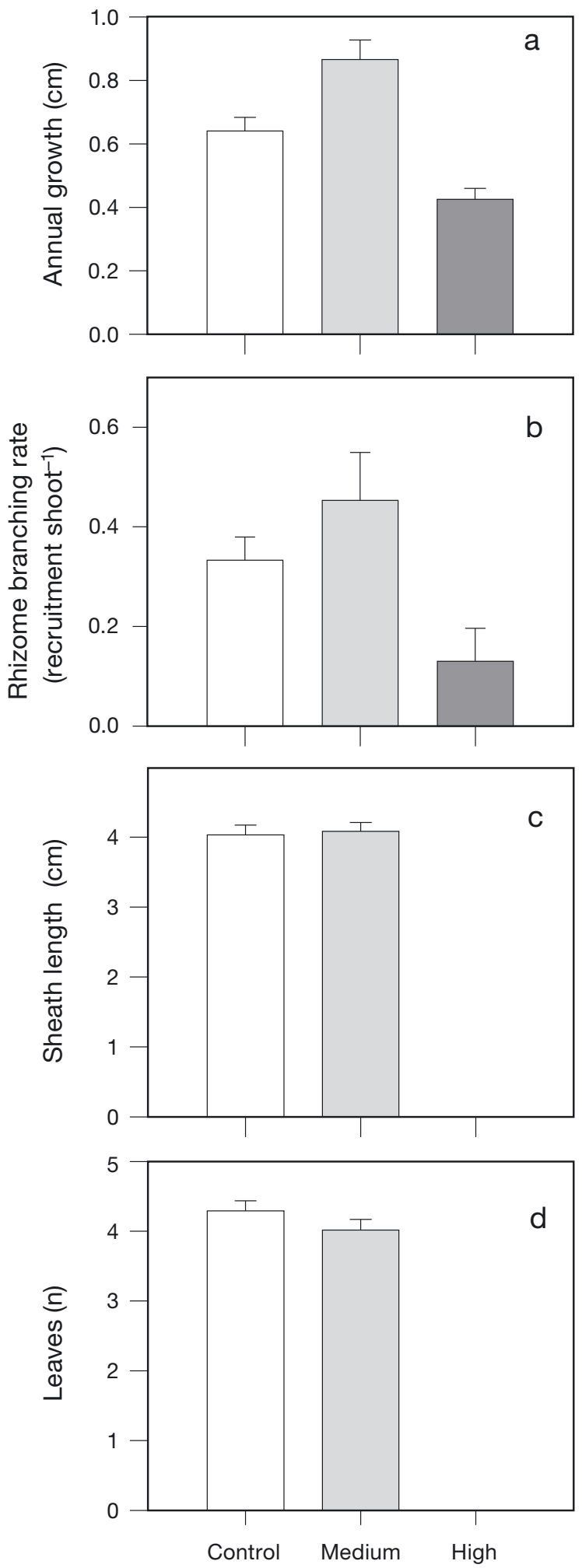

Fig. 2. Posidonia oceanica. Sublethal responses of the seagrass to different levels of permanent burial (control, medium and high): (a) rhizome annual growth; (b) shoot branching; (c) sheath length; and (d) number of leaves. Responses were averaged for all 3 sites as no significant differences were observed between them 
Table 3. Posidonia oceanica. Average $( \pm \mathrm{SE})$ annual vertical growth $\left(\mathrm{cm} \mathrm{yr}^{-1}\right)$ of rhizomes at the 3 studied meadows (SHP $=$ Shallow Protected, SHE $=$ Shallow Exposed, DPE $=$ Deep Exposed) from the different sediment burial treatments

\begin{tabular}{|lccc|}
\hline Meadow & Control & Medium & High \\
\hline SHP & $0.49 \pm 0.04$ & $0.71 \pm 0.08$ & $0.37 \pm 0.04$ \\
SHE & $0.47 \pm 0.02$ & $0.51 \pm 0.02$ & $0.35 \pm 0.04$ \\
DPE & $0.91 \pm 0.07$ & $1.47 \pm 0.10$ & $0.61 \pm 0.05$ \\
\hline
\end{tabular}

Table 4. Posidonia oceanica. Results of ANOVAs to assess the effects of Burial Frequency, Burial Duration, and timing on \% seagrass shoot survival. C = control, $\mathrm{P}=$ permanent, $\mathrm{LF}=$ low frequency, $\mathrm{HF}=$ high frequency, $\mathrm{ST}=$ short-term, $\mathrm{MT}=$ mid-term, LT = long-term, $\mathrm{H}=$ high

\begin{tabular}{|lccccc|}
\hline Factor & df & MS & $F$ & $p$ & Tukey \\
\hline Meadow & 1 & 30.45 & 0.109 & 0.746 & \\
Frequency & 3 & 14014.06 & 50.149 & $<\mathbf{0 . 0 0 1}$ & C > P = LF = HF \\
Meadow $\times$ Frequency & 3 & 30.45 & 0.109 & 0.954 & \\
Error & 16 & 279.45 & & & \\
Duration & 3 & 7165.51 & 128.58 & $\mathbf{< 0 . 0 0 1}$ & C > ST = MT = LT \\
Error & 8 & 55.73 & & & \\
Meadow & 2 & 96.52 & 0.275 & 0.762 & \\
Timing & 1 & 588.86 & 1.675 & 0.210 & C > H \\
Burial & 1 & 51609.10 & 146.81 & $<\mathbf{0 . 0 0 1}$ & \\
Meadow $\times$ Timing & 2 & 312.49 & 0.889 & 0.427 & \\
Meadow $\times$ Burial & 2 & 114.34 & 0.325 & 0.726 & \\
Timing $\times$ Burial & 1 & 289.48 & 0.824 & 0.375 & \\
Meadow $\times$ Timing $\times$ Burial & 2 & 530.58 & 1.509 & 0.245 & \\
Error & 20 & 351.53 & & & \\
\hline
\end{tabular}

burial duration also had strong and equivalent deleterious effects on shoot density. Whether seagrass was submitted to burial for 22,42 or $77 \mathrm{~d}$, shoot density was 0 by the end of the experimental period (Table 4, Fig. 4). On the other hand, the negative effect of sediment burial on shoot population did not differ between the 2 periods when the experiments were conducted (Table 4, Fig. 5).

\section{DISCUSSION}

Sediment burial strongly enhanced population decline of the seagrass Posidonia oceanica, regardless of frequency, duration or timing at which the burial event occurred. Even very moderate $(4 \mathrm{~cm})$ sediment additions (relative to plant size, with leaves ca. $50 \mathrm{~cm}$ in length; Alcoverro et al. 1995) caused $50 \%$ population decline in 8 to 12 wk. In those cases we detected some response capacity to burial, consisting of rhizome elongation and rhizome branching. When burial levels were above $9 \mathrm{~cm}$, however, no response was observed and most affected shoots died (90 to $100 \%$ population decline).

Natural disturbances like storms and anthropogenic coastal interventions such as beach nourishment or harbour
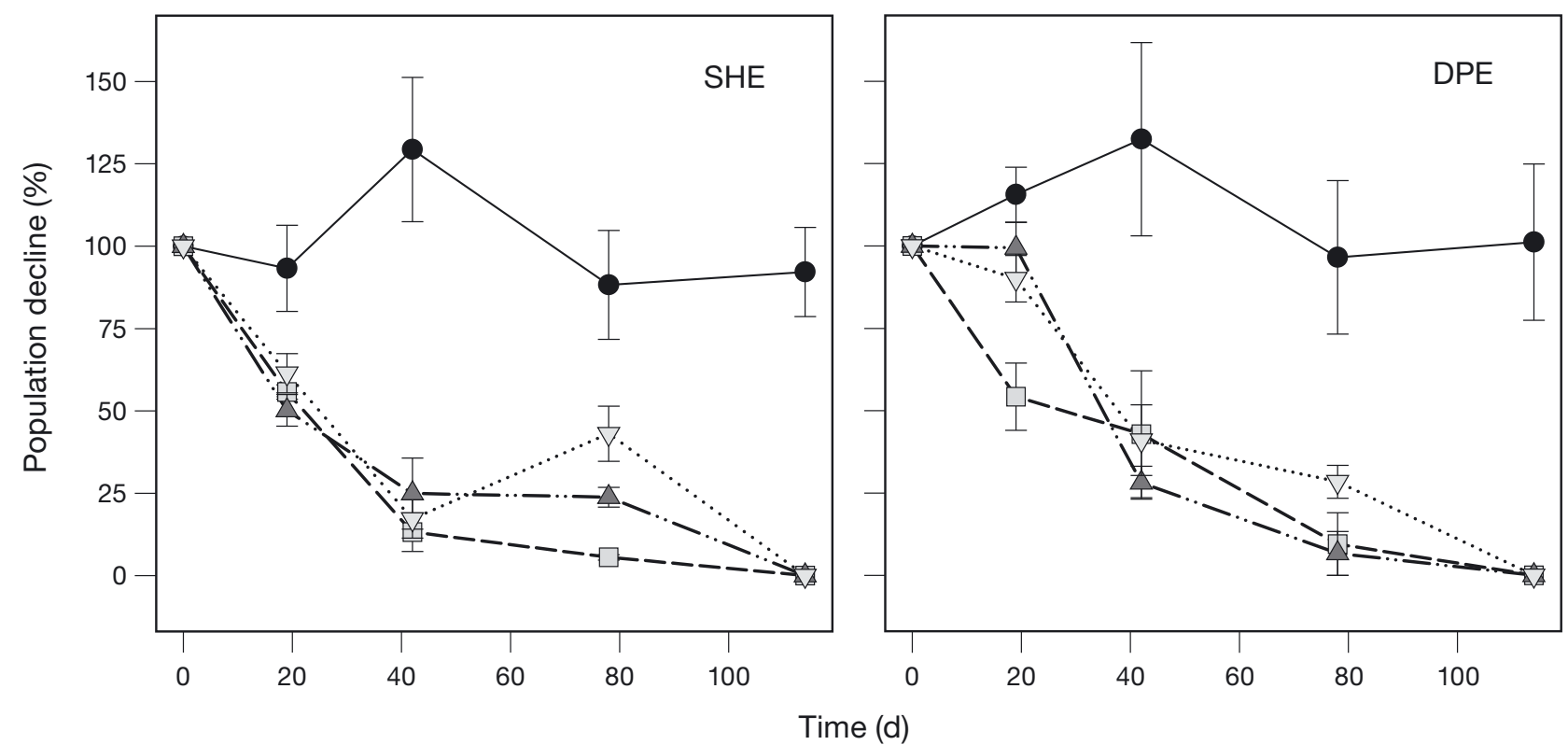

Fig. 3. Posidonia oceanica. Trends in population decline of shoots (surviving number of shoots, expressed as a percentage relative to the initial $\pm \mathrm{SE}$ ) exposed to different frequencies of burial: control (no sand: $\bullet$ ), permanent (115 d: $\nabla)$, low frequency (30 d: $\Delta$ ), and high frequency (15 d: $\square)$ in the Shallow Exposed (SHE) and Deep Exposed (DPE) meadows 


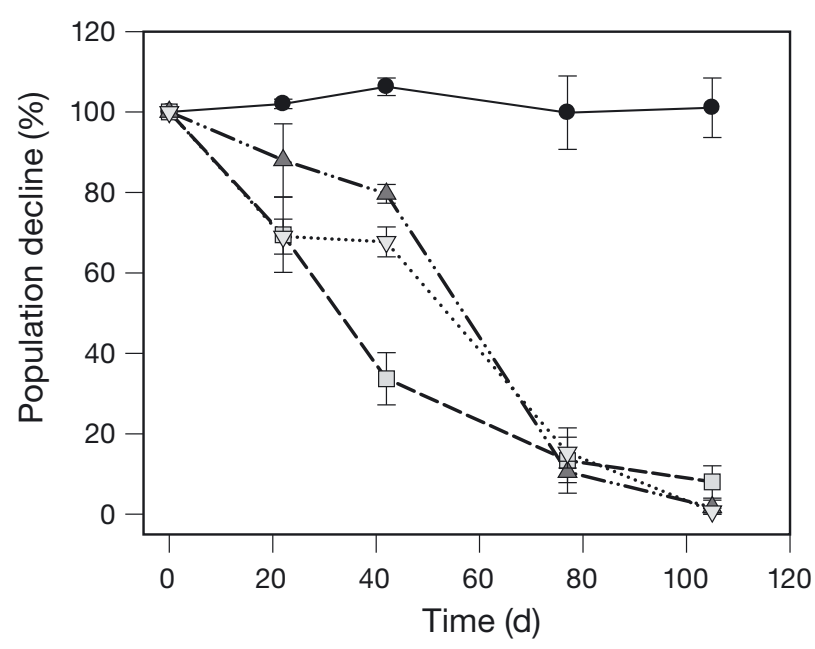

Fig. 4. Posidonia oceanica. Trends in population decline of shoots (surviving number of shoots, expressed as a percentage relative to the initial) exposed to different burial durations: control (no sand: $\bullet$ ), short-term (22 d: $\square)$, mid-term (42 d: $\boldsymbol{\Delta}$ ), and long-term $(77 \mathrm{~d}: \nabla)$
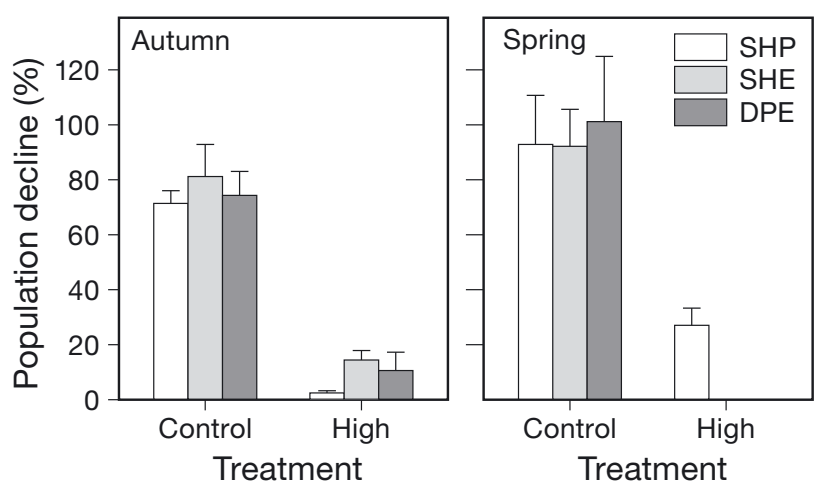

Fig. 5. Posidonia oceanica. Seasonal trends in population decline of shoots (surviving number of shoots, expressed as a percentage relative to the initial) exposed to 2 levels of permanent burial: control $(0 \mathrm{~cm})$, and high $(9 \mathrm{~cm})$ at the different sites $(\mathrm{SHP}=$ Shallow Protected, $\mathrm{SHE}=$ Shallow Exposed, DPE $=$ Deep Exposed

constructions result in sporadic sediment depositions in seagrass meadows (Erftemeijer \& Lewis 2006, González-Correa et al. 2009). These sediments can often persist in the meadow for several months, but in the case of species like Posidonia oceanica, even shortterm sediment depositions can severely affect the meadow survival. The effect of burial intensity has been studied for several seagrass species, for which the critical thresholds (50\% of shoot reduction) are, on average, around $10 \mathrm{~cm}$. However, some fast-growing species can reach $50 \%$ shoot mortality at burial levels of only $2 \mathrm{~cm}$ (see review by Cabaço et al. 2008). In fact, seagrass responses to burial seem to be species-specific and strongly size-dependent, with larger plants, and particularly those with vertical rhizomes and large rhizome diameter, better counteracting burial than small-sized plants (Cabaço et al. 2008). P. oceanica is one of the largest seagrasses in the world and has rhizomes that protect the meristems from sedimentation, which should make it much more able to withstand burial in comparison to other species (as has been observed for P. australis or P. sinuosa; Ruiz 2000, Cabaço et al. 2008). In contrast, our results indicate that even modest depth burial with respect to the size of the shoots leads to enhanced population decline of $P$. oceanica. Indeed, even though we provide experimental evidence that this species has a certain capacity to react to sublethal burial, the plant also appears to present important architectural limitations, and P. oceanica would appear be able to respond to only relatively low burial intensities.

Plant response to burial is characterised by an increase in rhizome elongation and plant ramification rate, among others (Cabaço et al. 2008). In our experiments, a few centimetres of sand addition increased seagrass vertical annual growth up to $50 \%$ compared to controls, which has also been observed for other species under similar conditions (Cymodocea nodosa, Marbà \& Duarte 1994; Thalassia hemprichii, Duarte et al. 1997). One of the mechanisms involved in the stimulation or inhibition of vertical rhizome growth seems to be related to light, as shown for C. nodosa (Terrados 1997). There are also some compounds such as ethylene (phytohormone), which, under anoxic conditions, enhance rhizome elongation of some amphibious and aquatic plants and increase the formation of new stems in dune plants (e.g. Ammophila breviligulata; Voesenek et al. 1998). In seagrass species dominating highly dynamic ecosystems (e.g. C. nodosa and C. rotundata; Marbà \& Duarte 1995, Duarte et al. 1997), higher rhizome branching rate is a typical mechanism for enhancing local shoot recruitment after disturbance. In addition, this mechanism also seems to take place in less dynamic species such as T. hempricii (Duarte et al. 1997) or Posidonia oceanica (this work) when submitted to experimental burial.

Plant reaction to medium burial $(4 \mathrm{~cm})$ was not homogeneous. Plants responded to burial by increasing vertical growth in all the studied meadows, but the magnitude of that increase differed substantially among them. These discrepancies were mostly related to basal plant traits, that is, the differences observed in vertical growth among the controls from the different meadows. For example, there was a stronger response in the meadow where vertical growth was already high (DPE meadow). Under low sediment burial levels, plasticity in growth and ramification could play an important role in determining population survival, giving certain meadows a higher capacity to counteract 
sedimentation than others. In this work, the maximum vertical growth rates found in the most-responding meadow (ca. $1.5 \mathrm{~cm} \mathrm{yr}^{-1}$ ) were in agreement with the maximum values reported for Posidonia oceanica plants which are adapted to highly dynamic sediment regimes (1.5 to $2 \mathrm{~cm} \mathrm{yr}^{-1}$; Boudouresque et al. 1984). However, in our study, such growth rates were not high enough to totally counteract the $4 \mathrm{~cm}$ of sand burial, as a reduction of ca. $50 \%$ of the initial density was observed.

The cause of intraspecific differences in plant vertical growth rates is not well understood, but could result from site-related factors such as light availability or sediment type (Terrados 1997), as well as local adaptation to periodical burial events of low magnitude. This is in concordance with field observations reported for meadows submitted to different sedimentary conditions (Boudouresque et al. 1984). These authors found that meadows with none or very light sedimentation rates displayed low rates of 'rhizome endogenous growth' (only $0.5 \mathrm{~cm} \mathrm{yr}^{-1}$ ), while other meadows submitted to sedimentation rates as high as 6 to $7 \mathrm{~cm} \mathrm{yr}^{-1}$ exhibited vertical rhizome growth rates of 1.5 to $2 \mathrm{~cm} \mathrm{yr}^{-1}$, which are in agreement with our results (Table 3). Such plasticity in growth makes predicting plant responses to burial more difficult, unless some basal parameters of the plant are known.

Apart from burial intensity, this work has considered other attributes of sediment disturbance, indicating that, at a burial level of $9 \mathrm{~cm}$, shoot density is severely affected, independently of duration, frequency or timing of the event. Although frequency and duration of extreme disturbances can be as important as intensity in affecting ecosystems (Brander 2007, Halpern et al. 2007, Cardoso et al. 2008), only a few studies have directly addressed the effects of those parameters in marine systems. For instance, some modelling approaches have evaluated the importance of frequency and/or duration of different factors such as hypoxic events, trawling or overfishing on marine communities (Hiddink et al. 2006, Mumby 2006, Allen 2007, Shields \& Weidman 2008). The role of frequency, duration or timing in determining consequences of disturbances in terrestrial systems has received more attention, and examinations of sedimentation frequency on perennial sand dune plants also highlight the existence of a critical threshold burial level at $1 \mathrm{~m}$ of sand, above which mortality is independent of the frequency of burial events (Maun 1984).

The causes of population decline induced by sediment burial were not specifically examined in this study, but in situ observations suggest that necrosis occurring at the leaf meristem, which becomes apparent after 2 wk of burial, may be driving mortality. Such necrosis could result from the anoxia observed at the surface sediment in the burial experiments. Sediment anoxia can be directly deleterious in seagrasses which have basal growth meristems (e.g. Thalassia testudinum; in Carlson et al. 1994). Under anoxic conditions, sulphides invade internal plant tissues, reaching high toxic levels and causing shoot mortality (e.g. Zostera marina; Goodman et al. 1995, Borum et al. 2005, Mascaró et al. 2009). Furthermore, the enhanced addition of organic matter resulting from shoot mortality can create a sharp decrease in oxygen levels which further increase anoxic conditions (see Carlson et al. 1994, Terrados et al. 1999). This would be particularly aggravated by the high proportion of belowground biomass in Posidonia oceanica (78 to $87 \%$, Romero et al. 1992), as has also been suggested for $T$. testudinum (Carlson et al. 1994). Another mechanism that may also enhance plant mortality is the reduction of leaf surface area and the subsequent decrease in photosynthesis and oxygen levels in the meristem (Fitzpatrick \& Kirkman 1995, Cebrian et al. 1998, Terrados et al. 1999).

Overall, this work provides experimental evidence that, despite its large size compared to other seagrasses Posidonia oceanica is very sensitive to burial beyond relatively low thresholds $(4 \mathrm{~cm})$. Storms and other natural disturbances could play a very important role in limiting the distribution of $P$. oceanica meadows, particularly in shallow waters or in meadows located in front of open beaches, which are characterised by highly dynamic sediment regimes. In this context, the synergistic influences of sediment movement caused by human modifications of coastal regions could potentially push many shallow meadows over their inherent tolerance thresholds of burial. Its high mortality under moderate sediment arrivals and low capacity to recover and recolonise could be among the main causes of $P$. oceanica regressions in the Mediterranean Sea. Therefore, sedimentation effects on $P$. oceanica need to be specifically examined for disturbances that increase burial beyond a threshold, independently of their timing, duration or frequency. When protection management plans are being designed, implemented and executed, and when environmental consequences have to be defined, it should be noted that even low sediment loads during a short period of time can be very damaging and should be prevented and minimised for these emblematic seagrass ecosystems.

Acknowledgements. The authors thank X. de Pedro, O. Invers, M. A. Rodríguez and M. Pérez for their invaluable help with field work, and G. Kendrick for comments and suggestions that greatly helped during the manuscript preparation. This work received financial support from ECC (RIACON Project, MAS2-CT94-0084). Additional funds also came from the grants CGL2007-66771-C02-01 and CGL2009-12562 from the Spanish Ministry of Science and Innovation. 


\section{LITERATURE CITED}

Alcoverro T, Duarte CM, Romero J (1995) Annual growth dynamics of Posidonia oceanica: contribution of largescale versus local factors to seasonality. Mar Ecol Prog Ser 120:203-210

Allen JI (2007) Effects of demersal trawling on ecosystem functioning in the North Sea: a modelling study. Mar Ecol Prog Ser 336:63-75

Astier JM (1984) Impacts des aménagements littoraux de la Rade de Toulon, liés aux techniques d'endinage, sur les herbiers à Posidonia oceanica. In: Boudoresque CF, Grissac AJd (eds) International workshop on Posidonia oceanica beds. GIS Posidonie Publishers, Marseille, p 255-259

Badalamenti F, Carlo GD, D'Anna G, Gristina M, Toccaceli M (2006) Effects of dredging activities on population dynamics of Posidonia oceanica (L.) Delile in the Mediterranean Sea: The case study of Capo Feto. Hydrobiologia 555:253-261

Bailard JA (1981) An energetics total load sediment transport model for a plane sloping beach. J Geophys Res 86: 10938-10954

Blanc JJ, Grissac AJD (1989) Réflexions géologiques sur la régression des herbiers à Posidonies (Departaments du Var et des Bouches-du Rhone). In: Boudouresque CF, Meinesz A, Fresi E, Gravez V (eds) International workshop on Posidonia oceanica beds. GIS Posidonie Publishers, Marseille, p 273-285

Boer WF (2007) Seagrass-sediment interactions, positive feedbacks and critical thresholds for occurrence, a review. Hydrobiologia 591:5-24

Borum J, Pedersen O, Greve TM, Frankovich TA, Zieman JC, Fourqurean JW, Madden CJ (2005) The potential role of plant oxygen and sulphide dynamics in die-off events of the tropical seagrass, Thalassia testudinum. J Ecol 93:148-158

Boudouresque CF, Jeudy de Grissac A, Meinesz A (1984) Relations entre le sedimentation et l'allongement des rhizomes orthotropes de Posidonia oceanica dans la baie d'Elbu (Corse). In: Boudouresque CF, Jeudy de Grissac A Olivier J (eds) International workshop on Posidonia oceanica beds. GIS Posidonie Publishers, Marseille, p 185-191

Bourcier M (1989) Régression des herbiers à Posidonia oceanica (L.) Delile a l'Est de Marseille, sous l'action conjugée des activites humaines et des modifications climatiques. In: Boudouresque CF, Meinesz A, Fresi E, Gravez V (eds) International workshop on Posidonia oceanica beds. GIS Posidonie Publishers, Marseille, p 287-292

Brander KM (2007) Global fish production and climate change. Proc Natl Acad Sci USA 104:19709-19714

> Cabaço S, Santos R, Duarte CM (2008) The impact of sediment burial and erosion on seagrasses: a review. Estuar Coast Shelf Sci 79:354-366

> Cardoso PG, Raffaelli D, Pardal MA (2008) The impact of extreme weather events on the seagrass Zostera noltii and related Hydrobia ulvae population. Mar Pollut Bull 56: 483-492

Carlson PR Jr, Yabro LA, Barber TR (1994) Relationship of sediment sulfide to mortality of Thalassia testudinum in Florida bay. Bull Mar Sci 54:733-746

Cebrian J, Duarte CM, Agawin NSR, Merino M (1998) Leaf growth response to simulated herbivory: a comparison among seagrass species. J Exp Mar Biol Ecol 220:67-68

Clarke SM, Kirkman H (1989) Seagrass dynamics. In: Larkum AWD, McComb AJ, Shepherd SA (eds) Biology of seagrasses. Elsevier, Amsterdam, p 304-345

Crouzet A, Boudouresque CF, Meinesz A, Pergent G (1983) Evidence of the annual character of cyclic changes of Posi- donia oceanica scale thickness (erect rhizomes). Rapp Comm Int Mer Méditerr 28:113-114

Cruz-Palacios V, van Tussenbroek BI (2005) Simulation of hurricane-like disturbances on a Caribbean seagrass bed. J Exp Mar Biol Ecol 324:40-60

Duarte CM (2002) The future of seagrass meadows. Environ Conserv 29:192-206

Duarte CM, Terrados J, Agawin NSR, Fortes MD, Bach S, Kenworthy WJ (1997) Response of a mixed Philippine seagrass meadow to experimental burial. Mar Ecol Prog Ser 147:285-294

> Duarte CM, Middelburg JJ, Caraco N (2005) Major role of marine vegetation on the oceanic carbon cycle. Biogeosciences $2: 1-8$

Erftemeijer PLA, Lewis RRR III (2006) Environmental impacts of dredging on seagrasses: a review. Mar Pollut Bull 52: 1553-1572

> Fitzpatrick J, Kirkman H (1995) Effects of prolonged shading stress on growth and survival of seagrass Posidonia australis in Jervis Bay, New South Wales, Australia. Mar Ecol Prog Ser 127:279-289

Fourqurean JWR, Rutten LM (2004) The impact of Hurricane Georges on soft-bottom, back reef communities: Site- and species-specific effects in south Florida seagrass beds. Bull Mar Sci 75:239-257

Gacia E, Duarte CM (2001) Sediment retention by a Mediterranean Posidonia oceanica meadow: the balance between deposition and resuspension. Estuar Coast Shelf Sci 52: 505-514

> González-Correa JM, Fernández-Torquemada Y, SánchezLizaso JL (2009) Short-term effect of beach replenishment on a shallow Posidonia oceanica meadow. Mar Environ Res 68:143-150

Goodman JL, Moore KA, Dennison WC (1995) Photosynthetic responses of eelgrass (Zostera marina L.) to light and sediment sulfide in a shallow barrier island lagoon. Aquat Bot 50:37-47

> Halpern BS, Selkoe KA, Micheli F, Kappel CV (2007) Evaluating and ranking the vulnerability of global marine ecosystems to anthropogenic threats. Conserv Biol 21: 1301-1315

Hiddink JG, Jennings S, Kaiser MJ (2006) Indicators of the ecological impact of bottom-trawl disturbance on seabed communities. Ecosystems 9:1190-1199

Jeudy de Grissac A, Boudouresque CF (1985) Rôles des herbieres de phanérogames marines dans les mouvements des sédiments côtiers: les herbieres a Posidonia oceanica. Colloque Franco-Japonais d'Océanographie 1: $143-151$

Lionello P, Boldrin U, Giorgy F (2008) Future changes in cyclone climatology over Europe as inferred from a regional climate simulation. Clim Dyn 30:657-671

Marbà N, Duarte CM (1994) Growth response of the seagrass Cymodocea nodosa to experimental burial and erosion. Mar Ecol Prog Ser 107:307-311

> Marbà N, Duarte CM (1995) Coupling of seagrass (Cymodocea nodosa) patch dynamics to subaqueous dune migration. J Ecol 83:381-389

> Marbà N, Duarte CM (1998) Rhizome elongation and seagrass clonal growth. Mar Ecol Prog Ser 174:269-280

> Marbà N, Cebrián J, Enríquez S, Duarte CM (1994a) Migration of large-scale subaqueous bedforms measured with seagrass (Cymodocea nodosa) as tracers. Limnol Oceanogr 39:126-133

> Marbà N, Gallegos ME, Merino M, Duarte CM (1994b) Vertical growth of Thalassia testudinum: seasonal and interannual variability. Aquat Bot 47:1-11 
Mascaró O, Valdemarsen T, Holmer M, Pérez M, Romero J (2009) Experimental manipulation of sediment organic content and water column aeration reduces Zostera marina (eelgrass) growth and survival. J Exp Mar Biol Ecol 373:26-34

Maun MA, Lapierre J (1984) The effects of burial by sand on Ammophila breviligulata. J Ecol 72:827-839

Mazzella L, Buia MC, Gambi MC, Lorenti M, Russo GF, Scipione MB, Zupo V (1992) Plant-animal trophic relationships in the Posidonia oceanica ecosystem of the Mediterranean Sea: a review. In: John DM, Hawkins SJ, Price JH (eds) Plant-animal interactions in the marine benthos, Vol 46. Clarendon Press, Oxford, p 165-187

Mortsch LD (1998) Assessing the impact of climate change on the great lakes shoreline wetlands. Clim Change 40: 391-416

> Mumby PJ (2006) The impact of exploiting grazers (Scaridae) on the dynamics of Caribbean coral reefs. Ecol Appl 16: $747-769$

Pérès JM (1984) La regression des herbiers a Posidonia oceanica. In: Boudouresque CF, Jeudy De Grissac A, Olivier J (eds) International workshop on Posidonia beds, Vol 1. GIS Posidonie Publishers, Marseille, p 445-454

> Pergent G, Pergent-Martini C (1991) Leaf renewal cycle and primary production of Posidonia oceanica in the bay of Lacco Ameno (Ischia, Italy) using lepidochronological analysis. Aquat Bot 42:49-66

Philippart CJM (1994) Interactions between Arenicola marina and Zostera noltii on a tidal flat in the Wadden Sea. Mar Ecol Prog Ser 111:251-257

Preen AR, Long WJL, Coles RG (1995) Flood and cyclone related loss, and partial recovery, of more than $1000 \mathrm{~km}^{2}$ of seagrass in Hervey Bay, Queensland, Australia. Aquat Bot 52:3-17

Quinn GP, Keough MJ (2002) Experimental design and data analysis for biologists. Cambridge University Press

Romero J, Pergent G, Pergent-Martini C, Mateo MA, Regnier C (1992) The detritic compartment in a Posidonia oceanica meadow: litter features, decomposition rates and mineral stocks. PSZNI: Mar Ecol 13:69-83

Ruiz JM (2000) Respuesta de la fanerógama marina Posidonia oceanica (L.) Delile a perturbaciones antrópicas. $\mathrm{PhD}$ thesis, Universidad de Murcia

Ruiz JM, Romero J (2003) Effects of disturbances caused by coastal constructions on spatial structure, growth dynamics and photosynthesis of the seagrass Posidonia oceanica. Mar Pollut Bull 46:1523-1533

Ruiz JM, Boudouresque CF, Enríquez S (2009) Mediterranean seagrasses. Bot Mar 52:369-381

Editorial responsibility: Hans Heinrich Janssen, Oldendorf/Luhe, Germany
Sánchez-Lizaso JL, Guillén JE, Ramos A (1990) The regression of Posidonia oceanica meadows in El Campello (Spain). Rapp Comm Int Mer Médit 32(1), B-1 10,17

Shepherd SA, McComb AJ, Bulthuis DA, Neverauskas V, Steffensen DA, West R (1989) Decline of seagrass. In: Larkum AWD, McComb AJ, Shepherd SA (eds) Biology of seagrasses. Elsevier, New York, p 346-393

Shields E, Weidman C (2008) A quantitative approach to characterizing hypoxic events. J Coast Res Spec Issue 55:50-58

Short FT, Neckles HA (1999) The effects of global climate change on seagrass. Aquat Bot 63:169-196

Short FT, Wyllie-Echevarria S (1996) Natural and humaninduced disturbance of seagrasses. Environ Conserv 23: $17-27$

- Suchanek TH (1983) Control of seagrass communities and sediment distribution by Callianassa (Crustacea, Thalassinidea) bioturbation. J Mar Res 41:281-298

> Terrados J (1997) Is light involved in the vertical growth response of seagrasses when buried by sand? Mar Ecol Prog Ser 152:295-299

> Terrados J, Duarte CM, Kamp-Nielsen L, Agawin NSR and others (1999) Are seagrass growth and survival constrained by the reducing conditions of the sediment? Aquat Bot 65:175-197

> Valentine JF, Heck KL Jr, Harper P, Beck M (1994) Effects of bioturbation in controlling turtlegrass (Thalassia testudinum Banks ex König) abundance: evidence from field enclosures and observations in the Northern Gulf of Mexico. J Exp Mar Biol Ecol 178:181-192

Vermaat JE, Agawin NSR, Duarte CM, Enríquez S, Fortes MD, Uri JS, van Vierssen W (1997) The capacity of seagrasses to survive increased turbidity and siltation: the significance of growth forms and light use. Ambio 26:499-504

Vizzini S, Sarà G, Michener RH, Mazzola A (2002) The role and contribution of the seagrass Posidonia oceanica (L.) Delile organic matter for secondary consumers as revealed by carbon and nitrogen stable isotope analysis. Acta Oecol 23:277-285

> Voesenek LACJ, van der Putten WH, Maunn MA (1998) The role of ethylene and darkness in accelerated shoot elongation of Ammophila breviligulata upon sand burial. Oecologia 115:359-365

Walker DI, McComb AJ (1992) Seagrass degradation in Australian coastal waters. Mar Pollut Bull 25:191-195

> Waycott M, Duarte CM, Carruthers TJB, Orth RJ, and others (2009) Accelerating loss of seagrasses across the globe threatens coastal ecosystems. Proc Natl Acad Sci USA 106: $12377-12381$

Submitted: June 15, 2010; Accepted: December 2, 2010 Proofs received from author(s): January 31, 2011 